Article

\title{
Genetic Diversity and Population Differentiation of Calanthe tsoongiana, a Rare and Endemic Orchid in China
}

\section{Xin Qian, Cai-xia Wang and Min Tian*}

Research Institution of Subtropical Forestry, Chinese Academy of Forestry, 73, Daqiao Road, Fuyang 311400, Zhejiang, China; E-Mails: qianxin090@163.com (X.Q.); cxwanghn@163.com (C.W.)

* Author to whom correspondence should be addressed;

E-Mail: tmin115@126.com or tmin115@163.com; Tel./Fax:+86-571-6310-5077.

Received: 20 August 2013; in revised form: 24 September 2013 / Accepted: 25 September 2013 / Published: 14 October 2013

\begin{abstract}
Calanthe tsoongiana is a rare terrestrial orchid endemic to China, and this species has experienced severe habitat loss and fragmentation. Inter-simple sequence repeat (ISSR) markers were employed to assess the genetic diversity and differentiation of six populations of $C$. tsoongiana. Based on 124 discernible fragments yielded by eleven selected primers, high genetic diversity was revealed at the species level; however, genetic diversity at the population level was relatively low. High-level genetic differentiation among populations was detected based on analysis of molecular variance (AMOVA), indicating potential limited gene flow. No significant relationship was observed between genetic and geographic distances among the sampled populations. These results suggested that restricted gene flow might be due to habitat fragmentation and reduced population size as a result of human activities. Based on the findings, several conservation strategies were proposed for the preservation of this threatened species.
\end{abstract}

Keywords: Calanthe tsoongiana; genetic diversity; ISSR; conservation; Orchidaceae

\section{Introduction}

Orchidaceae is one of the largest families of flowering plants, with approximately 25,000 species comprising up to $10 \%$ of all angiosperms, including five subfamilies and about 870 genera [1]. More than any other plant family, however, Orchidaceae has a large proportion of threatened species that only survive in specific environments and may be particularly susceptible to habitat fragmentation and 
deterioration caused by human activities, such as over-collection, due to their ornamental and medicinal value [1]. Therefore, worldwide orchid populations are often small and isolated and have increasingly been a major subject of conservation concern. The orchid genus, Calanthe $\mathrm{R}$. Br., is widely distributed in tropical, subtropical and warm temperate regions from Africa to Asia and the Pacific Islands. It is characterized by distichous plicate leaves, basal or lateral inflorescences, pseudobulbous or cane-like stems made up of several internodes, similar petals and sepals, normally spurred lips and possession of eight pollinia [2]. This genus contains approximately 171 species worldwide, 40 of which inhabit China [2]. Calanthe tsoongiana T. Tang et F.T. Wang is a rare perennial orchid endemic to China and is mainly distributed in Fujian, Guizhou, Hunan, Jiangxi and Zhejiang provinces [3]. They usually grow in forest margins and rocky slopes at elevations of 300 to $1500 \mathrm{~m} \mathrm{[3]}$. The habitat range and population size of C. tsoongiana has declined acutely during the last several decades, due to climatic change, agriculture, urbanization, silviculture and mass collection for horticultural use and sale. Many populations recorded previously have disappeared, and current distributions are highly fragmented and isolated. Recently, this species has been listed as a national second class protection species in China [4]. Except for its taxonomic and morphologic characteristics, however, this species has been poorly studied. To date, nothing is known about its within-population or its intra-specific genetic diversity and population structure among the distribution areas.

Comprehensive knowledge on genetic diversity and population structure is essential for species conservation, as it reflects the status and survival potential of populations [5]. The maintenance of genetic diversity is very important for the long-term survival of a species, because loss of genetic variation within populations may significantly decrease adaptability to environmental change and increase extinction risk [6]. Disappearance of an individual population will remove any unique biological traits that it possesses and may ultimately lead to species extinction [6]. George et al. [7] suggested that examining the patterns and levels of genetic diversity within and structuring among populations can help in understanding evolutionary mechanisms, such as genetic drift and mutation operating at the population and species level and can serve as an indicator of the extent of gene flow and population divergence. Among various molecular tools for genetic analysis, inter-simple sequence repeat (ISSR) is a powerful tool for conservation genetic study, due to its greater reliability and reproducibility of bands, resolution of a high number of polymorphic fragments and relatively low cost [8-10]. In addition, because no prior knowledge of target sequences is required for ISSR, this marker is especially suited to rare orchids, where few or no molecular genetic studies have been previously conducted [8,11]. Furthermore, ISSR has been used successfully for studying population genetics in several orchid species, including Piperia yadonii [7], Cymbidium goeringii [11], Tipularia discolor [12], Platanthera aquilonis [13], P. dilatata [13], P. huronensis [13], Gastrodia elata [14] and Dendrobium fimbriatum [15]. Consequently, the aim of the present study on the genetic diversity and structure of $C$. tsoongiana was to contribute to the pool of background genetic information and to suggest conservation schemes from a genetic perspective. 


\section{Results}

\subsection{Genetic Diversity of C. tsoongiana}

In total, 104 individuals from six C. tsoongiana populations generated 124 clear and discernible bands using eleven selected ISSR primers, of which 120 (96.8\%) were polymorphic (Table 1). This indicated that the ISSR markers measured sufficient polymorphism for DNA typing in the population genetic study of $C$. tsoongiana. The number of fragments yielded per primer varied from eight to 14 , with an average of 11.3. The size of the amplified products ranged from 100 to $2000 \mathrm{bp}$. Genetic diversity was relatively low at the population level (percentage of polymorphic loci, $P P L=50 \%$; Nei's gene diversity, $H=0.183$; Shannon's Information index, $I=0.271$; observed number of alleles, $N_{\mathrm{a}}=1.500$; effective number of alleles, $N_{\mathrm{e}}=1.318$ ) and shifted variably across different sites. The highest and lowest levels of genetic diversity were found in SZ $(P P L=72.6 \% ; H=0.284 ; I=0.415)$ and $\mathrm{WN}(P P L=30.7 \% ; H=0.119 ; I=0.174)$, respectively. However, the natural populations of $C$. tsoongiana had high levels of genetic diversity at the species level $\left(P P L=96.8 \% ; H=0.398 ; I=0.576 ; N_{\mathrm{a}}=1.968\right.$; $\left.N_{\mathrm{e}}=1.720\right)$.

Table 1. Genetic diversity within the populations of C. tsoongiana.

\begin{tabular}{cccccc}
\hline Populations & $\boldsymbol{N}_{\mathrm{a}}$ & $\boldsymbol{N}_{\mathrm{e}}$ & $\boldsymbol{H}$ & $\boldsymbol{I}$ & $\boldsymbol{P P L}$ \\
\hline LA & $1.419(0.496)$ & $1.286(0.378)$ & $0.163(0.206)$ & $0.239(0.296)$ & $41.9 \%$ \\
RJ & $1.524(0.501)$ & $1.314(0.377)$ & $0.182(0.200)$ & $0.273(0.287)$ & $52.4 \%$ \\
SZ & $1.726(0.448)$ & $1.504(0.389)$ & $0.284(0.201)$ & $0.415(0.282)$ & $72.6 \%$ \\
TR & $1.694(0.463)$ & $1.379(0.360)$ & $0.226(0.192)$ & $0.342(0.271)$ & $69.4 \%$ \\
WN & $1.307(0.463)$ & $1.210(0.356)$ & $0.119(0.191)$ & $0.174(0.274)$ & $30.7 \%$ \\
WYS & $1.331(0.472)$ & $1.215(0.351)$ & $0.122(0.191)$ & $0.180(0.275)$ & $33.1 \%$ \\
Average & $1.500(0.474)$ & $1.318(0.369)$ & $0.183(0.197)$ & $0.271(0.281)$ & $50.0 \%$ \\
Species Level & $1.968(0.177)$ & $1.720(0.285)$ & $0.398(0.129)$ & $0.576(0.164)$ & $96.8 \%$ \\
\hline
\end{tabular}

$N_{\mathrm{a}}$ : observed number of alleles; $N_{\mathrm{e}}$ : effective number of alleles; $H$ : Nei's gene diversity; $I$ : Shannon's Information index; $P P L$ : the percentage of polymorphic loci; values in brackets are standard deviations.

\subsection{Genetic Differentiation and Gene Flow in C. tsoongiana}

The total genetic diversity $\left(H_{\mathrm{t}}\right)$ of the species was 0.406 , and the genetic diversity within populations $\left(H_{\mathrm{s}}\right)$ was 0.183 . The coefficient of genetic differentiation among populations $\left(G_{\mathrm{st}}\right)$ was about 0.55 , indicating that $55 \%$ of the genetic variation was among the populations and $45 \%$ was within the populations. The analysis of molecular variance (AMOVA) result $\left(\Phi_{\mathrm{pt}}=0.522\right)$ further revealed that a large proportion of genetic differentiation was partitioned among populations, and the differences among populations were highly significant $(p=0.001)$ (Table 2) [16]. These findings were consistent with the relatively low gene flow value $\left(N_{\mathrm{m}}=0.408\right)$ obtained among populations. 
Table 2. Analysis of molecular variance (AMOVA) for the populations of $C$. tsoongiana.

\begin{tabular}{cccccccc}
\hline SV & d.f. & SSD & MSD & VC & TVP & $\boldsymbol{\Phi}_{\mathbf{p t}}$ & $\boldsymbol{p}$ (rand $\geq$ data) \\
\hline Among populations & 5 & 1252.535 & 250.507 & 13.878 & $52 \%$ & 0.522 & 0.001 \\
Within populations & 98 & 1246.456 & 12.719 & 12.719 & $48 \%$ & & \\
Total & 103 & 2498.991 & & 26.597 & $100 \%$ & & \\
\hline
\end{tabular}

SV: source of variation; d.f.: degree of freedom; SSD: sum of squares; MSD: mean squares; VC: variance component; TVP: total variance percentage; $\Phi_{\mathrm{pt}}$ : the proportion of the total variance among populations.

\subsection{Genetic Relationships among C. tsoongiana Populations}

The Nei's genetic distance among the $C$. tsoongiana populations ranged from 0.229 (between LA and WYS) to 0.638 (between WN and WYS) (Table 3). The Mantel test indicated that there was no significant correlation between genetic distance and geographic distance $(r=0.088, p=0.306)$ (Figure 1). The UPGMA dendrogram showed general separation of the six populations, but a few individuals from four populations (RJ, JR, SZ and TR) were cluster mixed (not shown). All 104 plants were clustered into two major groups, three populations (LA, WYS and RJ) and two individuals from SZ and two from TR formed the first group, while the second group included the remaining three populations (SZ, TR and WN). Two-dimensional principal coordinate analysis (PCoA) of the six populations accounted for $43.94 \%$ (first axis) and $21.14 \%$ (second axis) of total variance, respectively (Figure 2). The first axis separated the six populations into two major groups, which accorded with cluster analysis, and the LA and WYS populations occupied a similar position along the second axis. There was a clear peak in the value of $\Delta K(127.2)$ at $K=2$ (Figure 3). Therefore $K=2$ best fit the data. The proportions of all individuals were assigned into two clusters (Figure 4), but the RJ and SZ populations displayed some degree of mixed ancestry, which was analogous to the result of UPGMA dendrogram.

Table 3. Nei's original measures of genetic identity (above diagonal) and genetic distance (below diagonal) among the populations of $C$. tsoongiana.

\begin{tabular}{ccccccc}
\hline Populations & LA & RJ & SZ & TR & WN & WYS \\
\hline LA & - & 0.744 & 0.699 & 0.640 & 0.541 & 0.796 \\
RJ & 0.296 & - & 0.756 & 0.757 & 0.572 & 0.727 \\
SZ & 0.359 & 0.280 & - & 0.749 & 0.670 & 0.634 \\
TR & 0.447 & 0.279 & 0.290 & - & 0.789 & 0.591 \\
WN & 0.615 & 0.558 & 0.401 & 0.237 & - & 0.528 \\
WYS & 0.229 & 0.319 & 0.456 & 0.527 & 0.638 & - \\
\hline
\end{tabular}


Figure 1. Relationship between genetic and geographic distance in the populations of C. tsoongiana.

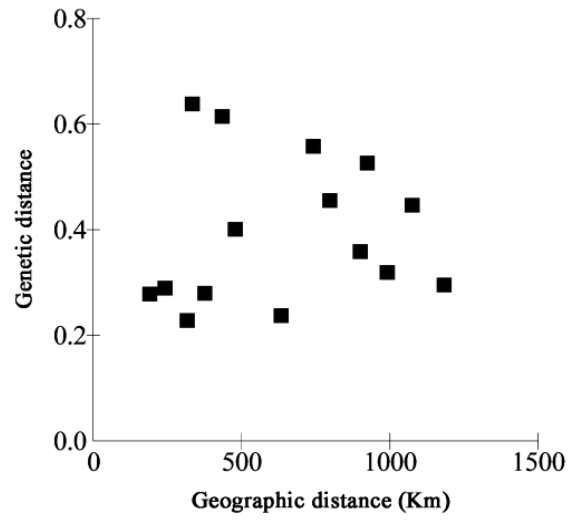

Figure 2. The principal coordinate analysis (PCoA) plot of six populations of C. tsoongiana based on the two principal axes (first axis $=43.94 \%$, second axis $=21.14 \%$ ).

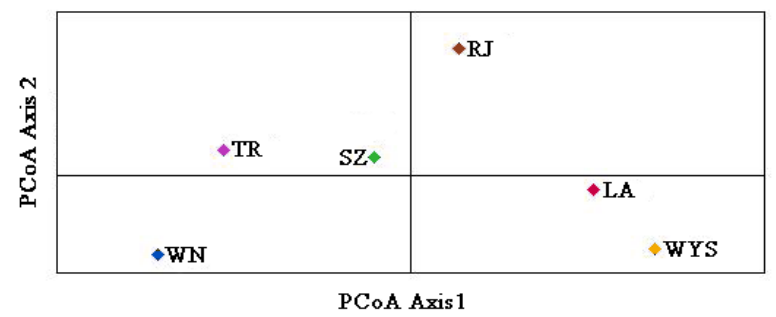

Figure 3. Results of the Bayesian assignment analysis using the Structure Harvester.

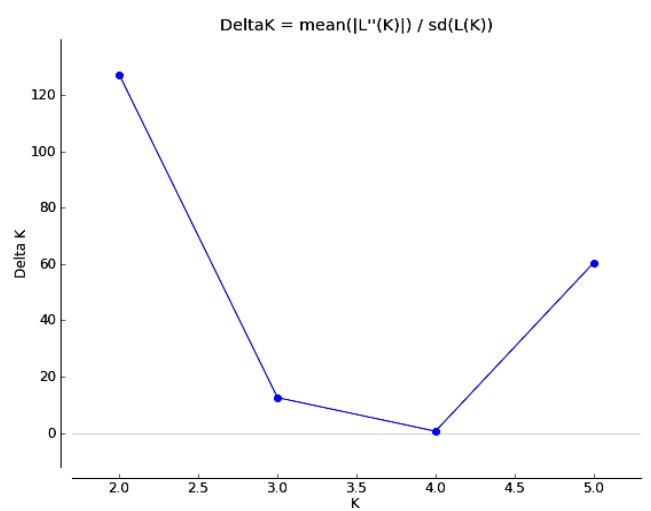

Figure 4. Population structure of six populations of $C$. tsoongiana prepared using the STRUCTURE program (Pritchard Lab, Stanford University, CA, USA).

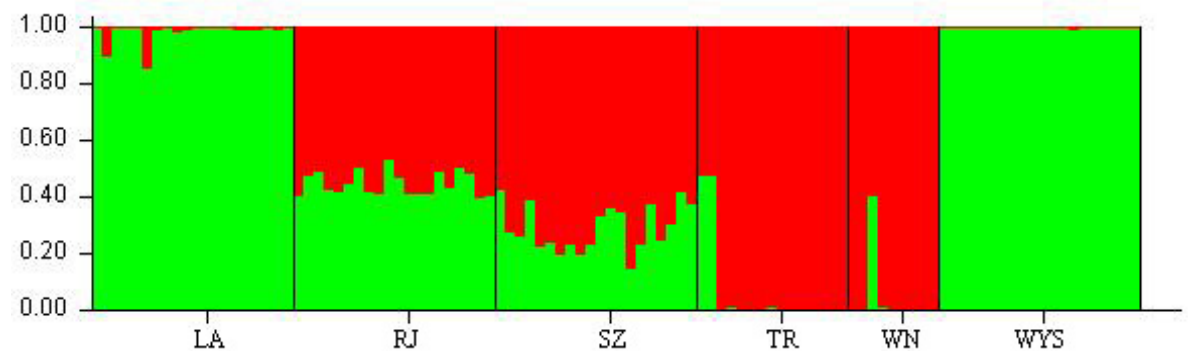




\section{Discussion}

\subsection{Genetic Diversity}

To the best of our knowledge, only a few reports exist on the conservation genetics of the Calanthe genus. Chung et al. [17] studied the levels and distribution of genetic diversity in Calanthe discolor, C. reflexa and $C$. sieboldii using allozyme technology and found that genetic variation varied at the species and population level. Kim et al. [2] found high levels of polymorphism within three Calanthe taxa, including C. sieboldii, $C$. discolor and C. bicolor. The results of the present study revealed that the genetic diversity of $C$. tsoongiana was low at the population level, but high at the species level. Similar outcomes have been found in several other orchid species based on dominant DNA markers, for example, Gastrodia elata [14], Piperia yadonii [7] and Cymbidium goeringii [11] by inter simple sequence repeat (ISSR), Dendrobium officinale [18] and Liparis japonica [19] by amplified fragment length polymorphism (AFLP) and Dendrobium loddigesii by sequence related amplified polymorphism (SRAP) [20].

Generally, widespread species tend to possess higher genetic diversity than endangered and endemic species [21]. However, some studies have shown that rare or endemic species can also have high genetic diversity [22,23]. C. tsoongiana exhibited a significantly higher genetic diversity at the species level $(H=0.3978)$ than the average value for perennial herbs $(H=0.1240)$ [24] and many other orchids $[12,13,15]$. This may be a reflection of the historical pattern of genetic variation in C. tsoongiana, that is, a previously wide distribution and only becoming rare recently. In addition, because some distribution areas were influenced by Pleistocene glaciers [25], the current genetic diversity at the species level may be a result of its refuge history. The high diversity in this species may also be related to their perennial long-life habits, which could provide more opportunity to accumulate mutants or special microstructures in different populations due to biotic processes [26].

Genetic diversity within populations is influenced by many factors, such as mating systems, population size, extended time periods with low numbers of individuals, genetic drift and gene flow [7,27]. The mean within-population diversity of $C$. tsoongiana $(H=0.1826)$ was lower than the average value of plant genetic diversity reported by Nybom [28] based on ISSR $(H=0.22)$. This pattern could be attributed to several factors. Firstly, the population sizes of $C$. tsoongiana were small, with only $15(\mathrm{WN})$ to 33 (SZ) individuals found, due to habitat destruction and illegal collection. In some cases, plants had become locally extinct in locations recorded in previous literature. Prolonged periods of small population size and population fragmentation can lead to loss in genetic diversity due to the founder effect, genetic bottlenecks and loss of rare alleles [29]. A population with an effective size of 50 is considered the minimum to maintain sufficient genetic variability, while 500 individuals are required to offset effective drift [30]. The relatively high level of genetic diversity within the SZ and TR populations might be because population size reduction occurred very recently in these two locations, especially where that reduction has presented within a generation or two [31]. Secondly, self-incompatibility is very important to maintain high genetic diversity in populations [32]. According to our previous field investigations (unpublished data), however, C. tsoongiana is self-compatible. Additionally, decreased genetic diversity can occur due to geitonogamy if flowers on an inflorescence are receptive at the same time, and pollinators frequently interpollinate consecutive flowers on the 
same inflorescence [7]. Thirdly, a low seed germination rate due to a lack of endosperm and mycorrhizal requirements, low fruit set and vegetative propagation might also lead to relatively low genetic diversity in C. tsoongiana within populations [33].

Table 4. Genetic differentiation among populations of orchid species based on dominant DNA markers.

\begin{tabular}{|c|c|c|c|c|c|c|}
\hline Orchid Species & $\mathbf{A M}$ & $N_{\mathrm{P}}$ & $N_{\mathrm{I}}$ & $N_{\mathrm{L}}$ & $G_{\text {st }}\left(F_{s t}\right)$ & SR \\
\hline Piperia yadonii (2006) & ISSR & 7 & 210 & 636 & 0.42 & {$[7]$} \\
\hline Piperia yadonii (2007) & ISSR & 8 & 251 & 622 & 0.39 & [7] \\
\hline Cymbidium goeringii & ISSR & 11 & 325 & 127 & 0.22 & [11] \\
\hline Tipularia discolor & ISSR & 4 & 56 & 22 & 0.42 & [12] \\
\hline Platanthera aquilonis & ISSR & 7 & 111 & 164 & 0.70 & [13] \\
\hline Platanthera dilatata & ISSR & 10 & 152 & 339 & 0.49 & [13] \\
\hline Platanthera huronensis & ISSR & 14 & 236 & 517 & 0.36 & [13] \\
\hline Gastrodia elata & ISSR & 14 & 483 & 77 & 0.27 & [14] \\
\hline Dendrobium fimbriatum & ISSR & 5 & 114 & 117 & 0.75 & [15] \\
\hline Calanthe tsoongiana & ISSR & 6 & 104 & 124 & 0.55 & This study \\
\hline Zeuxine strateumatica & RAPD & 10 & 50 & 71 & 0.92 & [34] \\
\hline Eulophia sinensis & RAPD & 7 & 38 & 97 & 0.65 & [34] \\
\hline Zeuxine gracilis & RAPD & 6 & 74 & 77 & 0.54 & [34] \\
\hline Goodyera procera & RAPD & 14 & 343 & 101 & 0.39 & [35] \\
\hline Platanthera leucophaea & RAPD & 10 & 192 & 64 & 0.26 & [36] \\
\hline Paphiopedilum micranthum & RAPD & 4 & 161 & 131 & 0.20 & [37] \\
\hline Changnienia amoena & RAPD & 11 & 216 & 119 & 0.43 & [38] \\
\hline Cattleya labiata & RAPD and ISSR & 7 & 117 & 272 & 0.13 & [26] \\
\hline Vanda coerulea & RAPD and ISSR & 7 & 32 & 226 & 0.04 & [39] \\
\hline Liparis loeselii & AFLP & 12 & 155 & 108 & 0.38 & {$[5]$} \\
\hline Dendrobium officinale & AFLP & 12 & 71 & 195 & 0.27 & [18] \\
\hline Liparis japonica & AFLP & 8 & 185 & 406 & 0.43 & [19] \\
\hline Spiranthes romanzoffiana & AFLP & 17 & 205 & 138 & 0.89 & [40] \\
\hline Phragmipedium longifolium & AFLP & 6 & 160 & 365 & 0.20 & [41] \\
\hline Himantoglossum hircinum & AFLP & 20 & 211 & 215 & 0.15 & [42] \\
\hline Orchis mascula & AFLP & 15 & 293 & 196 & 0.08 & [43] \\
\hline Orchis purpurea & AFLP & 9 & 244 & 70 & 0.09 & [44] \\
\hline Dactylorhiza incarnata & AFLP & 12 & 250 & 91 & 0.35 & [45] \\
\hline Cypripedium japonicum & AFLP & 6 & 180 & 377 & 0.52 & [46] \\
\hline Dendrobium loddigesii & SRAP & 7 & 92 & 231 & 0.30 & [20] \\
\hline
\end{tabular}

AM: assessment method; $N_{\mathrm{P}}$ : number of populations sampled; $N_{\mathrm{I}}$ : number of individuals sampled; $N_{\mathrm{L}}$ : number of loci analyzed; SR: source references; RAPD: random amplified polymorphic DNA.

\subsection{Genetic Differentiation}

Differentiation among the locations of $C$. tsoongiana $\left(G_{\mathrm{st}}=0.55\right)$ populations was higher than the average value $\left(G_{\mathrm{st}}=0.187\right)$ obtained from 76 orchid species reviewed by Forrest et al. [40]; however, the genetic differentiation values of 71 species $(93.4 \%)$ in the review were estimated by isozyme analysis, which may not be comparable to values estimated by DNA fragment markers [7,34]. 
Consequently, it triggered our own summary of levels of genetic differentiation among orchid populations estimated by dominant DNA markers (Table 4). The results showed that the values of $G_{\text {st }}$ ranged from 0.04 to 0.92 , with an average of 0.39 . Accordingly, $C$. tsoongiana exhibited relatively high population differentiation compared with other orchids performed by similar markers. This finding supported the low genetic diversity results within populations and the discreet UPGMA clustering of individuals from the same population. The greater similarity of individuals within rather than among the populations indicated that these populations were probably founded by one or a few individuals and that gene flow may be restricted among populations [13]. Gene flow (via pollen and seed) among the $C$. tsoongiana populations $\left(N_{\mathrm{m}}=0.4084\right)$ was below one, a level of migration that will not prevent continued divergence among populations [47]. Pollen transfer by insects among the populations would be very difficult, due to large geographic distances of more than $150 \mathrm{~km}$. Orchid seeds are usually capable of long-distance dispersal by wind, due to a high content of air and a small size. However, some authors have reported that most orchid seeds fall among maternal plants [48]. Li et al. [18] considered that tropical storms or typhoons may assist in seed dispersal, which may explain the over-lapping of individuals from RJ, TR, SZ and WN, as shown by STRUCTURE and UPGMA cluster analysis. Nevertheless, even if seeds are transported over great distances, they are unlikely to encounter the fungal symbiont needed for germination [30]. Therefore, it is likely that geographic isolation, habitat fragmentation, short pollinator movements and limited seed dispersal influence restricted gene flow among the $C$. tsoongiana populations. Genetic drift in continually small population sizes might also play an important role in shaping the present level of population differentiation [34]. The Mantel test indicated that there was no significant relationship between genetic distance and geographic distance, which was further confirmed by the UPGMA dendrogram and PCoA results. This pattern provided further evidence of the existence of genetic drift [49]. Using the STRUCTURE program, the 104 individuals from six C. tsoongiana populations were separated into two groups, further confirming that there was no genetic correlation of individuals with their spatial distribution. Similar results were also found in Liparis loeselii [5] and Liparis japonica [19], with the lack of visible spatial genetic structure in some cases possibly explained by sampled populations having a recent common origin [5].

\subsection{Implications for Conservation}

The ultimate goal of conservation is to ensure the continuous survival of populations and to maintain their evolutionary potential by preserving natural levels of genetic diversity [50]. In a species featuring low gene flow and high genetic differentiation among populations, each population is a special gene pool, and the loss of any such population can cause irreversible loss of genetic diversity [26]. In addition, in small-sized populations, genetic drift might lead to rapid genetic erosion and an increase in extinction risk [11]. Considering that $C$. tsoongiana maintains low within-population genetic diversity and high genetic differentiation among populations and that many of its native habitats and ecosystems have been destroyed by human disturbance, great effort should be made to preserve all extant populations and their habitats to prevent a further decrease in population size and to conserve the overall genetic base of this species. Collection of this orchid should be prohibited. Li and Ge [38] suggested that habitat protection should also protect relevant mycorrhizal 
fungi and pollinators, which are necessary to continue the lifecycle of orchid species and to maintain and recover their natural populations. A more robust and detailed legal protection policy should be enforced in the local county government, especially for the RJ, SZ and WN populations. Our study indicated an alarming situation for the WN and WYS populations, and pollen or mature seed transfer from other populations via human intervention may be an effective approach to create an artificial gene flow [6]. Transfer of mature plants between populations could also be an effective way to increase the genetic diversity. Furthermore, maintaining a germplasm bank for ex situ conservation is also recommended for C. tsoongiana. As discussed by Li et al. [18], populations (such as SZ and TR) possessing a higher genetic diversity should be given priority in seed banks. Finally, extensive and detailed ecological and biological studies on $C$. tsoongiana, including demographic dynamics, pollination biology, vegetative propagation and identification of fungal associates and germination ecology, should be conducted to achieve comprehensive conservation for this rare endemic orchid [17].

\section{Materials and Methods}

\subsection{Sample Collection}

Leaf samples were collected from 104 individuals representing six natural $C$. tsoongiana populations scattered throughout Fujian, Guizhou, Hunan, Jiangxi and Zhejiang provinces in south China (Figure 5). Each population was positioned by GPS, with location details listed in Table 5. Since the plant produces just two or three obovate-lanceolate or oblong leaves, only half of a fresh young blade was harvested from each healthy adult individual to minimize any deleterious effect on their growth. To prevent sampling within clones, leaves were obtained from individual plants located at least $3 \mathrm{~m}$ apart. The samples were dried with silica gel in zip-lock plastic bags and later stored at $-80{ }^{\circ} \mathrm{C}$ in the lab until DNA extraction. Voucher specimens were deposited at the Research Institution of Subtropical Forestry.

Figure 5. Map of six sampled populations of C. tsoongiana in China.
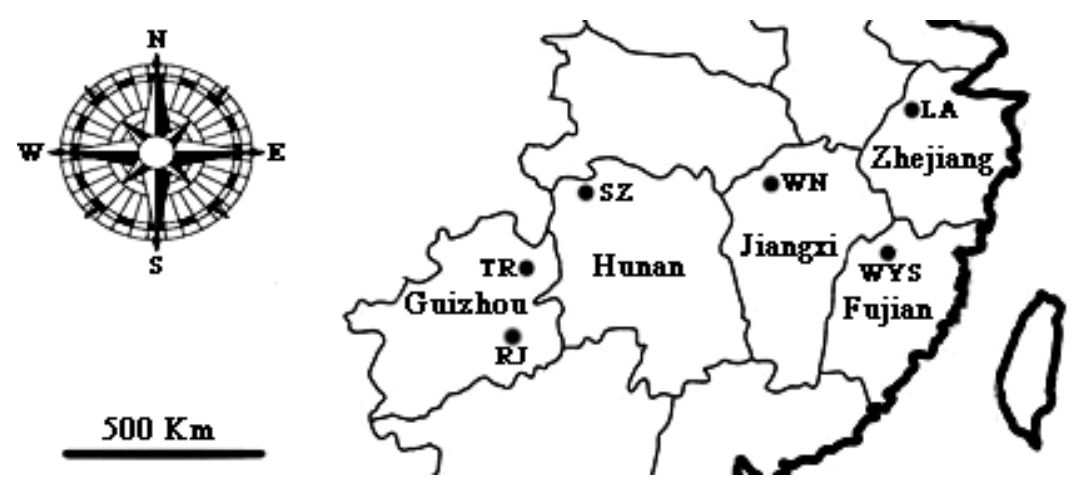
Table 5. Sampling details of different populations of C. tsoongiana in this study.

\begin{tabular}{cccccc}
\hline $\begin{array}{c}\text { Population } \\
\text { Code }\end{array}$ & Locality & $\begin{array}{c}\text { Geographical } \\
\text { Coordinate }\end{array}$ & $\begin{array}{c}\text { Altitude } \\
(\mathbf{m})\end{array}$ & $\begin{array}{c}\text { Sample } \\
\text { Size }\end{array}$ & $\begin{array}{c}\text { Voucher } \\
\text { Number }\end{array}$ \\
\hline LA & Linan county, Zhejiang & $30^{\circ} 21^{\prime} \mathrm{N}, 119^{\circ} 25^{\prime} \mathrm{E}$ & 1021 & 20 & $\mathrm{~J} 0611$ \\
RJ & Rongjiangcounty, Guizhou & $26^{\circ} 23^{\prime} \mathrm{N}, 108^{\circ} 12^{\prime} \mathrm{E}$ & 516 & 20 & $\mathrm{Q} 0516$ \\
SZ & Sangzhi county, Hunan & $29^{\circ} 40^{\prime} \mathrm{N}, 110^{\circ} 2^{\prime} \mathrm{E}$ & 363 & 20 & $\mathrm{Q} 0605$ \\
TR & Tongren county, Guizhou & $27^{\circ} 56^{\prime} \mathrm{N}, 180^{\circ} 36^{\prime} \mathrm{E}$ & 818 & 15 & $\mathrm{Q} 0521$ \\
WN & Wuning county, Jiangxi & $29^{\circ} 6^{\prime} \mathrm{N}, 115^{\circ} 17^{\prime} \mathrm{E}$ & 582 & 9 & $\mathrm{Q} 0418$ \\
WYS & Wuyishan county, Fujian & $27^{\circ} 44^{\prime} \mathrm{N}, 117^{\circ} 41^{\prime} \mathrm{E}$ & 705 & 20 & $\mathrm{Q} 0507$ \\
\hline
\end{tabular}

\subsection{DNA Extraction and PCR Amplification}

Total genomic DNA was exacted using a plant DNA isolation kit (NEP003-2, Dingguo Biotechnology, Beijing, China), according to the manufacturer's recommendations. The integrity of DNA samples were assessed through $0.7 \%$ agarose gels electrophoresis, and DNA quantification was performed in a Quawell Q5000 UV-Vis spectrophotometer (Quawell, San Jose, CA, USA). The DNA samples were diluted to $20 \mathrm{ng} / \mu \mathrm{L}$ in Tris-EDTA buffer solution and then stored at $-20{ }^{\circ} \mathrm{C}$ until further analysis.

Initially, 100 ISSR primers (set No. 9, University of British Columbia, Vancouver, Canada) synthesized by Sangon Biotech (Shanghai, China) were screened. Eleven primers (Table 6) that produced reproducible and clear bands and revealed high polymorphism were then selected for further study. The PCR was conducted in $25 \mu \mathrm{L}$ reaction volumes using optimized conditions as follows: $1 \times$ PCR buffer, $3 \mathrm{mM} \mathrm{Mg}{ }^{2+}, 0.3 \mathrm{mM}$ dNTP, $0.4 \mu \mathrm{M}$ primer, $60 \mathrm{ng}$ of DNA template and $1 \mathrm{U}$ of Taq DNA polymerase (Aidlab, Beijing, China). Negative controls, containing all ingredients except the DNA template, were included in each reaction to check the absence of contamination. Amplifications were carried out in a Vapo-protect Gradient thermal cycler (Bio-Rad, Hercules, CA, USA) using the following conditions: $94{ }^{\circ} \mathrm{C}$ for $5 \mathrm{~min}$ for initial denaturation, 40 cycles of denaturation at $94{ }^{\circ} \mathrm{C}$ for $1 \mathrm{~min}$, the appropriate annealing temperature (Table 6) for $1 \mathrm{~min}, 72{ }^{\circ} \mathrm{C}$ extension for $1 \mathrm{~min}$ and $72{ }^{\circ} \mathrm{C}$ for 10 min as a final extension. The PCR products stained with GelRed (Biotium, Hayward, CA, USA) were electrophoresed on $1.8 \%(w / v)$ agarose gels in $1 \times$ TBE buffer $(\mathrm{pH}=8.0)$ at $100 \mathrm{~V}$ for $90 \mathrm{~min}$, with DL2000 ladder (Takara, Shiga, Japan) used as the DNA molecular weight. After running, the gels were visualized and photographed under UV light using a gel analysis system (FR980, Shanghai, China). Each PCR reaction was repeated twice to ensure the reproducibility of the banding pattern.

Table 6. ISSR primers used in the present study.

\begin{tabular}{cccccc}
\hline $\begin{array}{c}\text { Primer } \\
\text { Name }\end{array}$ & $\begin{array}{c}\text { Sequence } \\
\left(\mathbf{5}^{\prime} \rightarrow \mathbf{3}^{\prime}\right)\end{array}$ & $\begin{array}{c}\text { Annealing } \\
\text { Temperature }\left({ }^{\circ} \mathbf{C}\right)\end{array}$ & $\begin{array}{c}\text { Primer } \\
\text { Name }\end{array}$ & $\begin{array}{c}\text { Sequence } \\
\left(\mathbf{5}^{\prime} \rightarrow \mathbf{3}^{\prime}\right)\end{array}$ & $\begin{array}{c}\text { Annealing } \\
\text { Temperature }\left({ }^{\circ} \mathbf{C}\right)\end{array}$ \\
\hline $\mathrm{UBC} 813$ & $(\mathrm{CT})_{8} \mathrm{~T}$ & 50 & $\mathrm{UBC} 845$ & $(\mathrm{CT})_{8} \mathrm{RG}$ & 52 \\
$\mathrm{UBC} 818$ & $(\mathrm{CA})_{8} \mathrm{G}$ & 52 & $\mathrm{UBC} 859$ & $(\mathrm{CG})_{8} \mathrm{RC}$ & 52 \\
$\mathrm{UBC} 824$ & $(\mathrm{TC})_{8} \mathrm{G}$ & 51 & $\mathrm{UBC} 868$ & $(\mathrm{GAA})_{6}$ & 48 \\
$\mathrm{UBC} 828$ & $(\mathrm{TG})_{8} \mathrm{~A}$ & 51 & $\mathrm{UBC} 873$ & $(\mathrm{GACA})_{4}$ & 49 \\
$\mathrm{UBC} 834$ & $(\mathrm{AG})_{8} \mathrm{YT}$ & 50 & $\mathrm{UBC} 881$ & $(\mathrm{GGGTG})_{3}$ & 56 \\
$\mathrm{UBC} 843$ & $(\mathrm{CT})_{8} \mathrm{RA}$ & 50 & & \\
\hline \multicolumn{5}{c}{$\mathrm{Y}=(\mathrm{C}, \mathrm{T}) ; \mathrm{R}=(\mathrm{A}, \mathrm{G})}$.
\end{tabular}




\subsection{Data Analysis}

The ISSR bands were scored as present (1) or absent (0) for each DNA sample to form a binary matrix. Only fragments showing consistent amplification were considered, while weak and smeared ones were excluded. The following genetic diversity parameters were determined for each population under the assumption that the populations were in Hardy-Weinberg equilibrium using POPGENE version 1.32 [51]: observed number of alleles $\left(N_{\mathrm{a}}\right)$; effective number of alleles $\left(N_{\mathrm{e}}\right)$; Nei's gene diversity $(H)$; Shannon's Information index $(I)$; percentage of polymorphic loci $(P P L)$; total genetic diversity $\left(H_{\mathrm{t}}\right)$, genetic diversity within populations $\left(H_{\mathrm{s}}\right)$, genetic differentiation among populations $\left(G_{\text {st }}\right)$; gene flow $\left(N_{\mathrm{m}}\right)$; and Nei's genetic identity and genetic distance. The same matrix was then used to perform cluster analysis, and an individual-level unweighted pair group was constructed with an arithmetic average (UPGMA) dendrogram using SAHN from NTSYS-pc version 2.20 [52].

Analysis of molecular variance (AMOVA) was used to estimate the variance components and their significance levels of genetic variation within and among the populations using GenAlEx version 6.5 [53] based on 999 permutations. The $\Phi_{\mathrm{pt}}$ values were also calculated and are considered analogous to $F_{\text {st }}$, describing the proportion of total variance among populations [54]. Principal coordinate analysis ( $\mathrm{PCoA})$ was also employed using the same software to detect the genetic relationships among populations.

A Mantel test for geographic and genetic distances of population pairs was performed to determine if a relationship existed between the two data matrices using TFPGA version 1.3 [55] with 999 permutations.

To infer population structure and estimate genetically homogeneous groups $(\mathrm{K})$ that best fit the data, the Bayesian Method was implemented in STRUCTURE version 2.3.4 [56], assuming the existence of $\mathrm{K}$ groups, characterized by a set of allele frequencies for each locus. An admixture model and the allele frequencies-correlated model were adopted, without prior assumptions concerning the population. The number of $K$ was set from 1 to 6 , and ten independent runs were performed, each with a Markov Chain Monte Carlo (MCMC) of 100,000 repetitions following a burn-in period of 50,000 iterations. Default values were kept for all other parameters. To identify the optimal value of $K$, the STRUCTURE output file was implemented in Structure Harvester version 0.6.93 [57], as per Evanno et al. [58].

\section{Conclusions}

Our results indicated that $C$. tsoongiana genetic diversity was high at the species level, but relatively low at the population level. High genetic differentiation was found among populations, which may be attributed to habitat fragmentation, due to anthropopression, geographic isolation, restricted gene flow and genetic drift. Based on these findings, several strategies were proposed for the conservation of this rare orchid.

\section{Acknowledgments}

We thank Xiaoling Niu, Jingjing Lian and Xingping Jiang for their assistance in field observation and sample collection. This work was supported by the Key Science and Technology Specific Projects 
of Zhejiang Province (No. 2012C12909-10) and the Science and Technology Projects of Zhejiang Forestry Department (No. 2012Y02-3).

\section{Conflicts of Interest}

The authors declare no conflict of interest.

\section{References}

1. Swarts, N.D.; Dixon, K.W. Terrestrial orchid conservation in the age of extinction. Ann. Bot. 2009, 104, 543-556.

2. Kim, S.H.; Lee, J.S.; Lee, G.J.; Kim, J.S.; Ha, B.K.; Kim, D.S.; Kim, J.B.; Kang, S.Y. Analyses of genetic diversity and relationships in four Calanthe taxa native to Korea using AFLP markers. Hort. Environ. Biotechnol. 2013, 54, 148-155.

3. Chen, X.Q.; Ji, Z.H.; Lang, K.Y.; Zhu, G.H. Flora Reipublicae Popularis Sinicae; Science Press: Beijing, China, 1999; Volume 18, pp. 279-281.

4. Subject Database of China Plant. Available online: http://www.plant.csdb.cn/protectlist (accessed on 18 August 2013).

5. Pillon, Y.; Qamaruz-Zaman, F.; Fay, M.F.; Hendoux, F.; Piquot, Y. Genetic diversity and ecological differentiation in the endangered fen orchid (Liparis loeselii). Conserv. Genet. 2007, 8, 177-184.

6. Izawa, T.; Kawahara, T.; Takahashi, H. Genetic diversity of an endangered plant, Cypripedium macranthos var. rebunense (Orchidaceae): Background genetic research for future conservation. Conserv. Genet. 2007, 8, 1369-1376.

7. George, S.; Sharma, J.; Yadon, V.L. Genetic diversity of the endangered and narrow endemic Piperia yadonii (Orchidaceae) assessed with ISSR polymorphisms. Am. J. Bot. 2009, 96, 2022-2030.

8. Rubio-Moraga, A.; Candel-Perez, D.; Lucas-Borja, M.E.; Tiscar, P.A.; Viñegla, B.; Linares, J.C.; Gómez-Gómez, L.; Ahrazem, O. Genetic diversity of Pinus nigra Arn. populations in Southern Spain and Northern Morocco revealed by Inter-Simple Sequence Repeat profiles. Int. J. Mol. Sci. 2012, 13, 5645-5658.

9. Farsani, T.M.; Etemadi, N.; Sayed-Tabatabaei, B.E.; Talebi, M. Assessment of genetic diversity of Bermudagrass (Cynodon dactylon) using ISSR markers. Int. J. Mol. Sci. 2012, 13, 383-392.

10. Golkar, P.; Arzani, A.; Rezaei, A.M. Genetic variation in Safflower (Carthamus tinctorious L.) for seed quality-related traits and Inter-Simple Sequence Repeat (ISSR) markers. Int. J. Mol. Sci. 2011, 12, 2664-2677.

11. Yao, X.H.; Gao, L.; Yang, B. Genetic diversity of wild Cymbidium goeringii (Orchidaceae) populations from Hubei based on inter-simple sequence repeats analysis. Front. Biol. China 2007. 2, 419-424.

12. Smith, J.L.; Hunter, K.L.; Hunter, R.B. Genetic variation in the terrestrial orchid Tipularia discolor. Southeast. Nat. 2002, 1, 17-26.

13. Wallace, L.E. A comparison of genetic variation and structure in the allopolyploid Platanthera huronensis and its diploid progenitors, Platanthera aquilonis and Platanthera dilatata. Can. J. Bot. 2004, 82, 244-252. 
14. Wu, H.F.; Li, Z.Z.; Huang, H.W. Genetic differentiation among natural populations of Gastrodia elata (Orchidaceae) in Hubei and germplasm assessment of the cultivated populations. Biodivers. Sci. 2006, 14, 315-326.

15. Ma, J.M.; Yin, S.H. Genetic diversity of Dendrobium fimbriatum (Orchidaceae), an endangered species, detected by inter-simple sequence repeat (ISSR). Acta Bot. Yunn. 2009, 31, 35-41.

16. Wei, L.; $\mathrm{Wu}$, X.J. Genetic variation and population differentiation in a medical herb Houttuynia cordata in China revealed by Inter-Simple Sequence Repeats (ISSRs). Int. J. Mol. Sci. 2012, 13, 8159-8170.

17. Chung, M.Y.; López-Pujol, J.; Maki, M.; Moon, M.O.; Hyun, J.O.; Chung, M.G. Genetic variation and structure within 3 endangered Calanthe Species (Orchidaceae) from Korea: Inference of population-establishment history and implications for conservation. J. Hered. 2013, 104, 248-262.

18. Li, X.X.; Ding, X.Y.; Chu, B.H.; Zhou, Q.; Ding, G.; Gu, S. Genetic diversity analysis and conservation of the endangered Chinese endemic herb Dendrobium officinale Kimura et Migo (Orchidaceae) based on AFLP. Genetica 2008, 133, 159-166.

19. Chen, X.H.; Guan, J.J.; Ding, R.; Zhang, Q.; Ling, X.Z.; Qu, B.; Zhang, L.J. Conservation genetics of the endangered terrestrial orchid Liparis japonica in Northeast China based on AFLP markers. Plant Syst. Evol. 2013, 299, 691-698.

20. Cai, X.Y.; Feng, Z.Y.; Zhang, X.X.; Xu, W.; Hou, B.W.; Ding, X.Y. Genetic diversity and population structure of an endangered orchid (Dendrobium loddigesii Rolfe) from China revealed by SRAP markers. Sci. Hortic. 2011, 129, 877-881.

21. Yu, H.H.; Yang, Z.L.; Sun, B.; Liu, R.N. Genetic diversity and relationship of endangered plant Magnolia officinalis (Magnoliaceae) assessed with ISSR polymorphisms. Biochem. Syst. Ecol. 2011, 39, 71-78.

22. Gonzalez-astorga, J.; Castillo-campos, G. Genetic variability of the narrow endemic tree Antirhea aromatica Castillo-Campos \& Lorence, (Rubiaceae,Guettardeae) in a tropical forest of Mexico. Ann. Bot. 2004, 93, 521-528.

23. Li, J.M.; Jin, Z.X. Genetic variation and differentiation in Torreya jackii Chun, an endangered plant endemic to China. Plant Sci. 2007, 172, 1048-1053.

24. Hamrick, J.L.; Godt, M.J.W. Allozyme Diversity in Plant Species. In Plant Population Genetics, Breeding, and Genetic Resources; Brown, A.H.D., Clegg, M.T., Kahler, A.L., Weir, B.S., Eds.; Sinauer Associates: Sunderland, MA, USA, 1990; pp. 43-63.

25. Shen, L.; Chen, X.Y.; Li, Y.Y. Glacial refugia and postglacial recolonization patterns of organisms. Acta Ecol. Sin. 2002, 22, 1983-1990.

26. Pinheiro, L.R.; Rabbani, A.R.C.; da Silva, A.V.C.; da Silva Lédo, A.; Pereira, K.L.G.; Diniz, L.E.C. Genetic diversity and population structure in the Brazilian Cattleya labiata (Orchidaceae) using RAPD and ISSR markers. Plant Syst. Evol. 2012, 298, 1815-1825.

27. Zhao, X.F.; Ma, Y.P.; Sun, W.B.; Wen, X.Y.; Milne, R. High genetic diversity and low differentiation of Michelia coriacea (Magnoliaceae), a critically endangered endemic in Southeast Yunnan, China. Int. J. Mol. Sci. 2012, 13, 4396-4411.

28. Nybom, H. Comparison of different nuclear DNA markers for estimating intraspecific genetic diversity in plants. Mol. Ecol. 2004, 13, 1143-1155. 
29. Barrett, S.C.H.; Kohn, J.R. Genetic and Evolutionary Consequences of Small Population Size in Plants: Implications for Conservation. In Genetics and Conservation of Rare Plants; Falk, D.A., Holsinger, K.E., Eds.; Oxford University Press: New York, NY, USA, 1991, pp. 3-30.

30. Brzosko, E.; Wróblewska, A.; Tałałaj, I.; Wasilewska, E. Genetic diversity of Cypripedium calceolus in Poland. Plant Syst. Evol. 2011, 295, 83-96.

31. Liu, J.F.; Shi, S.Q.; Chang, E.M.; Yang, W.J.; Jiang, Z.P. Genetic diversity of the critically endangered Thuja sutchuenensis revealed by ISSR markers and the implications for conservation. Int. J. Mol. Sci. 2013, 14, 14860-14871.

32. Eduardo, L.B.; Joaa, O.S.; George, J.S. Self-incompatibility, inbreeding depression and crossing potential in five Brazilian Pleurothallis (Orchidaceae) Species. Ann. Bot. 2001, 88, 89-99.

33. Lian, J.J.; Qian, X.; Wang, C.X.; Liu, F.; Tian, M. Ovule development and seed formation of Calanthe tsoongiana T. Tang et F.T. Wang. Acta Bot. Boreal.-Occident. Sin. 2013, 33, 494-500.

34. Sun, M.; Wong, K.C. Genetic structure of three orchid species with contrasting breeding systems using RAPD and allozyme markers. Am. J. Bot. 2001, 88, 2180-2188.

35. Wong, K.C.; Sun, M. Reproductive biology and conservation genetics of Goodyera procera (Orchidaceae). Am. J. Bot. 1999, 86, 1406-1413.

36. Wallace, L.E. Examining the effects of fragmentation on genetic variation in Platanthera leucophaea (Orchidaceae): Inferences from allozyme and random amplified polymorphic DNA markers. Plant Spec. Biol. 2002, 17, 37-49.

37. Li, A.; Luo, Y.B.; Ge, S. A preliminary study on conservation genetics of an endangered orchid (Paphiopedilum micranthum) from Southwestern China. Biochem. Genet. 2002, 40, 195-201.

38. Li, A.; Ge, S. Genetic variation and conservation of Changnienia amoena, an endangered orchid endemic to China. Plant Syst. Evol. 2006, 258, 251-260.

39. Manners, V.; Kumaria, S.; Tandon, P. SPAR methods revealed high genetic diversity within populations and high gene flow of Vanda coerulea Griff ex Lindl (Blue Vanda), an endangered orchid species. Gene 2013, 519, 91-97.

40. Forrest, A.D.; Hollingsworth, M.L.; Hollingsworth, P.M.; Sydes, C.; Bateman, R.M. Population genetic structure in European populations of Spiranthes romanzoffi ana set in the context of other genetic studies on orchids. Heredity 2004, 92, 218-227.

41. Muñoz, M.; Warner, J.; Albertazzi, F.J. Genetic diversity analysis of the endangered slipper orchid Phragmipedium longifolium in Costa Rica. Plant Syst. Evol. 2010, 290, 217-223.

42. Pfeifer, M.; Schatz, B.; Picó, F.X.; Passalacqua, N.G.; Fay, M.F.; Carey, P.D.; Jeltsch, F. Phylogeography and genetic structure of the orchid Himantoglossum hircinum (L.) Spreng. across its European central-marginal gradient. J. Biogeogr. 2009, 36, 2353-2365.

43. Jacquemyn, H.; Brys, R.; Adriaens, D.; Honnay, O.; Roldán-Ruiz, I. Effects of population size and forest management on genetic diversity and structure of the tuberous orchid Orchis mascula. Conserv. Genet. 2009, 10, 161-168.

44. Jacquemyn, H.; Vandepitte, K.; Brys, R.; Honnay, O.; Roldán-Ruiz, I. Fitness variation and genetic diversity in small, remnant populations of the food deceptive orchid Orchis purpurea. Biol. Conserv. 2007, 139, 203-210. 
45. Vandepitte, K.; Gristina, A.S.; de Hert, K.; Meekers, T.; Roldán-ruiz, I.; Honnay, O. Recolonization after habitat restoration leads to decreased genetic variation in populations of a terrestrial orchid. Mol. Ecol. 2012, 21, 4206-4215.

46. Qian, X.; Li, Q.J.; Lian, J.J.; Wang, C.X.; Tian, M. Genetic diversity of endangered wild Cypripedium japonicum populations: An AFLP analysis. Chinese J. Ecol. 2013, 32, 1445-1450.

47. Wright, S. The genetical structure of populations. Ann. Eugenic. 1949, 15, 323-354.

48. Fay, M.F.; Bone, R.; Cook, P.; Kahandawala, I.; Greensmith, J.; Harris, S.; Pedersen, H.; Ingrouille, M.J.; Lexer, C. Genetic diversity in Cypripedium calceolus (Orchidaceae) with a focus on north-western Europe, as revealed by plastid DNA length polymorphisms. Ann. Bot. 2009, 104, 517-525.

49. Dodd, S.C.; Helenurm, K. Genetic diversity in Delphinium variegatum (Ranunculaceae): A comparison of two insular endemic subspecies and their widespread mainland relative. Am. J. Bot. 2002, 89, 613-622.

50. Godt, M.J.W.; Hamrick, J.L. Allozyme variation in two Great Smoky Mountain endemics: Cacalia regalia and Glyceria nubigena. J. Hered. 1995, 86, 194-198.

51. POPGENE, version 1.32; Software for population genetic analysis; University of Alberta: Edmonton, AB, Canada, 1999.

52. NTSYS-pc, Numerical Taxonomy and Multivariate Analysis System, version 2.2; Exeter Software: Setauket, NY, USA, 2005.

53. Peakall, R.; Smouse, P.E. GenAlEx 6.5: Genetic analysis in excel. Population genetic software for teaching and research-An update. Bioinformatics 2012, 28, 2537-2539.

54. Excoffier, L.; Smouse, P.E.; Quattro, J.M. Analysis of molecular variance inferred from metric distances among DNA haplotypes: Application to human mitochondrial DNA restriction data. Genetics 1992, 131, 479-491.

55. Tools for Population Genetic Analyses (TFPGA), version 1.3; A Windows program for the analysis of allozyme and molecular population genetic data; Utah State University: Logan, UT, USA, 1997.

56. Pritchard, J.K.; Stephens, M.; Donnelly, P. Inference of population structure from multilocus genotype data. Genetics 2000, 155, 945-959.

57. Earl, D.A.; vonHoldt, B.M. STRUCTURE HARVESTER: A website and program for visualizing STRUCTURE output and implementing the Evanno method. Conserv. Genet. Resour. 2012, 4, 359-361.

58. Evanno, G.; Regnaut, S.; Goudet, J. Detecting the number of clusters of individuals using the software STRUCTURE: A simulation study. Mol. Ecol. 2005, 14, 2611-2620.

(C) 2013 by the authors; licensee MDPI, Basel, Switzerland. This article is an open access article distributed under the terms and conditions of the Creative Commons Attribution license (http://creativecommons.org/licenses/by/3.0/). 